\title{
Immunomodulatory Activity of Xestospongia sp. Ethanolic Extract Towards Interferon-gamma (IFN- $\gamma$ ) and Tumor Necrosis Factor-alpha (TNF- $\alpha$ ) Levels in Wistar Male Rats
}

\author{
Adryan Fristiohady ${ }^{1}$, Jumadil ${ }^{1}$, Wahyuni ${ }^{1}$, Muh. Hajrul Malaka ${ }^{1}$, Wa Ode Harnita ${ }^{1}$, Baru \\ Sadarun $^{2}$, Agung Wibawa Mahatva Yodha ${ }^{1}$, Saripuddin ${ }^{1}$, La Ode Muhammad Julian Purnama ${ }^{1}$, \\ Idin Sahidin ${ }^{*}$ \\ ${ }^{1}$ Faculty of Pharmacy, University of Halu Oleo, Kendari, 93232, Indonesia. \\ ${ }^{2}$ Faculty of Fisheries and Marine Science, University of Halu Oleo, Kendari, 93232, Indonesia. \\ *E-mail: sahidin02@uho.ac.id
}

\section{Article Info: \\ Received: 2 Agustus 2020 \\ in revised form: 21 Agustus 2020 \\ Accepted: 28 September 2020 \\ Available Online: 30 Seeptember 2020}

\section{Keywords: \\ Xestospongia $\mathrm{sp}$ \\ Immunomodulatory \\ IFN- $\gamma$ \\ TNF- $\alpha$.}

Corresponding Author:

Idin Sahidin

Faculty of Pharmacy

University of Halu Oleo

Kendari

93232

email:

sahidin02@uho.ac.id

\begin{abstract}
Xestospongia sp. is one of marine sponge belongs to demosponges class that mainly found in Southeast Sulawesi and the secondary metabolites contained in Xestospongia sp. suspected to have immunomodulatory activity. A previous study exhibited the immunomodulatory of Xestospongia sp. ethanolic extract (XEE) at dose of 300 and $400 \mathrm{mg} / \mathrm{Kg} \mathrm{BW}$ by affecting the phagocytic activity of macrophages. Thus, this study aims to investigate the effect of XEE towards interferon-gamma (IFN- $\gamma$ ) and tumor necrosis factoralpha (TNF- $\alpha$ ) at dose of 300 and $400 \mathrm{mg} / \mathrm{Kg} \mathrm{BW}$. Wistar male rats are divided into 4 groups $(n=6)$ randomly and treated for 7 days orally each as follow: group I (XEE dose of $300 \mathrm{mg} / \mathrm{KgBW}$ ); group II (XEE dose of 400 $\mathrm{mg} / \mathrm{KgBW}$ ); group III (0.5\% NaCMC); and group IV (commercial phylantii extract). On day 8, animals were infected with Staphylococcus aureus and left for 1 hour. Animals were sacrificed and the blood was drawn by cardiac puncture $(3 \mathrm{~mL})$, followed by analyzed under ELISA Kit for IFN- $\gamma$ and TNF- $\alpha$. Collected data were analyzed statistically using SPSS ${ }^{\circledR}$. The IFN- $\gamma$ levels obtained were $350.113 ; 392.970 ; 118.416$; and $61.958 \rho \mathrm{g} / \mathrm{mL}$, respectively and the TNF- $\alpha$ were 2808; 1308; 778; and $845.5 \mathrm{\rho g} / \mathrm{mL}$, respectively. According to results obtained, both doses of XEE are affecting the IFN- $\gamma$ and TNF- $\alpha$ levels $(p<0.05)$ compared to group III as negative control, and group IV as positive control. As conclusion, XEE of both doses is increasing IFN- $\gamma$ and TNF- $\alpha$ levels of animals that respond to phagocytic activity.
\end{abstract}

Copyright $@ 2019$ JFG-UNTAD

This open access article is distributed under a Creative Commons Attribution (CC-BY-NC-SA) 4.0 International license.

How to cite (APA $6^{\text {th }}$ Style):

Fristiohady, A., Jumadil., Wahyuni., Malaka, M. H., Harnita, W. O., Sadarun, B., Yodha, A. W. B., Saripuddin., Purnama, L.O. M. J., \& Sahidin, I. (2020). Immunomodulatory Activity of Xestospongia sp. ethanolic extract towards Interferongamma (IFN- $\gamma$ ) and Tumor Necrosis Factor-alpha (TNF- $\alpha$ ) Levels in Wistar Male Rats. Jurnal Farmasi Galenika : Galenika Journal of Pharmacy (e-Journal), 6(2), 303-308.doi:10.22487/j24428744.2020.v6.i2.15231 


\section{INTRODUCTION}

The immune system is the ability of host to prevent and eliminate antigens that potentially harmful to the host. The immune system consists of innate and adaptive immunity. Innate immunity is immunity that works as a barrier in the initiation of infection, including physical barriers such as epithelial cell layers, secreted mucus, and epithelial cilia. Biological fluids such as complement proteins, defensins, and ficolins, and cytokines, chemokines, reactive free radical species, and bioactive amines and enzymes are also categorized as innate immunity (Chaplin, 2010). Unlike the innate immunity, adaptive immunity is involving antigen-specific receptors on the surface of $\mathrm{T}$ and $\mathrm{B}$ cells (Chaplin, 2010).

As immunity drops, the threat of infection is vulnerable. Therefore, immunomodulatory agents are required. However, the use of immunomodulatory agents can cause side effects for long-term consumption. Thus, the discovery of novel agents as immunomodulatory is vital for the pharma search of immunomodulatory agents that safe and effected for long-term use. The drugs estimated about $40 \%$ are obtained from either natural products or their semi synthetical derivates (Lahlou, 2013).

Natural products derived from marine biodiversity is one of the potential choices for pharma search, and the marine sponges included. Marine sponge Xestospongia sp. has been known for its biological activities, including antihyperlipidemic, antibacterial, cytotoxic activity (Wahyuni et al., 2019; Turk et al., 2013; El-Gamal et al., 2016). In addition, Xestospongia sp. has immunomodulatory activity, specifically as immunostimulant (Fristiohady et al., 2019). According to previous research, ethanolic extract of Xestospongia sp. dose of 300 and $400 \mathrm{mg} / \mathrm{KgBW}$ were exhibiting immunostimulant activity by increasing the phagocytic activity of macrophages (Fristiohady et al., 2019).

Immunostimulant is characterized by the phagocytic activity of macrophages and activated by cytokines such as interferon-gamma (IFN- $\gamma$ ) and tumor necrosis factor-alpha (TNF- $\alpha$ ). The IFN- $\gamma$ is secreted by cells as inflammation stimuli or immune reaction occurs (Wahyuniati, 2017; Kaihena, 2013). On the other hand, the TNF- $\alpha$ is produced by macrophages that activate macrophages as well produced by activated macrophages (Parameswaran \&Patial, 2010; Sudiono, 2014).

The effect of ethanolic extract of Xestospongia sp. obtained from Southeast Sulawesi sea to IFN- $\gamma$ and TNF- $\alpha$ levels has not been reported yet. Thus, this research is conducted to examining the effect of ethanolic extract of Xestospongia sp. in immunostimulant activity by observing the IFN- $\gamma$ and TNF- $\alpha$ levels related to the phagocytic activity of macrophages.

\section{MATERIALS AND METHODS}

\section{Materials}

Apparatus used were rotary vacuum evaporator (Rotavapor, Buchi ${ }^{\circledR}$ ), blender (Philips), analytical balance $\left(\right.$ Precisa $\left.^{\circledR}\right)$, Erlenmeyer flask (pyrex), hot plate $\left(\right.$ Stuart $\left.{ }^{\circledR}\right)$, waterbath, centrifuge $\left(\right.$ Boeco $\left.^{\circledR}\right)$, EDTA-tube, and ELISA Rat IFN- $\gamma\left(\right.$ Invitrogen $\left.^{\circledR}\right)$ and LISA rat TNF- $\alpha$ (Elabscience $\left.{ }^{\circledR}\right)$ Kit.

The material used in this study were marine sponge Xestospongia sp., Wistar male rats, distilled water, 96\% ethanol $\left(\right.$ Mercks $\left.^{\circledR}\right), 0.5 \%$ Na CMC $\left(\right.$ Mercks $^{\circledR}$ ), Phylantii extract commercial (Stimuno ${ }^{\circledR}$ ), and pellet chow. All solutions used were analytical grade.

\section{Methods}

\section{Sample Collection and Determination}

Sample used were marine sponge Xestospongia sp. $(5.3 \mathrm{Kg}$ ) obtained from Bintang Samudra Edumarine park located in Konawe Regency of Southeast Sulawesi. The sponges were collected by hand in the reef flat and reef slope (2-5 m under sea levels) with using SCUBA. Collected samples were 
determined in Faculty of Fisheries and Marine Sciences of Halu Oleo University with document number $008 \mathrm{~b} / \mathrm{UN} 29.112 .1 .1 / \mathrm{pp} / 2018$. The sample collected was wetly sorted and washed under running water to cleanse the impurities. Followed by chopping the samples into pieces and put in water contained ice to eliminate the salts contained in sponges. Then samples were put in a sealed icebox for further investigation.

\section{Sample Extraction}

Sample $(5.3 \mathrm{Kg})$ was macerated with $96 \%$ ethanol $\left(\right.$ Mercks $\left.^{\circledR}\right)$ for 3 days, followed by filtration with filtrated paper (Whatmann ${ }^{\circledR}$ ) and replacing the solvent, thus obtained filtrate I, filtrate II, and filtrate III. The filtrates were then concentrated with rotary evaporator $\left(50^{\circ} \mathrm{C}\right)$ and yielded a total of $205.28 \mathrm{mg}$ concentrated extract $(3.87 \%)$.

\section{Bacteria Inoculation}

Staphylococcus aureus ATCC 25923 was planted in nutrient agar/ NA (Mercks ${ }^{\circledR}$ ) and incubated for 24 $\mathrm{h}$ at $37^{\circ} \mathrm{C}$ in incubator (Glorya Medica). In the following day, S. aureus was suspended in $0.9 \% \mathrm{NaCl}$ (Widatra $^{\circledR}$ ) until reaching the 0.5 McFarland turbidity.

\section{Animals}

24 Wistar male rats (250-300 g) were acclimatized for 7 days with standard rodent food and accessed to water ad libitum. Animals were used in this research are following ethical clearance issued by Halu Oleo University (No. 954/UN29.20/PPM/2019).

Animals were divided into 4 groups $(n=6)$, and treated for 7 days as follows: Group I : Phylantii extract commercial $\left(\right.$ Stimuno $^{\circledR}$ ) dose of $50 \mathrm{mg} / \mathrm{KgBW}$, as positive control, Group II : 0.5\% Na CMC, as negative control, Group III : Ethanolic extract of Xestospongia sp. dose of $300 \mathrm{mg} / \mathrm{KgBW}$ (EX300), and Group IV : Ethanolic extract of Xestospongia sp. dose of $400 \mathrm{mg} / \mathrm{KgBW}$ (EX400)

On day 8, the blood from each animal was collected by cardiac puncture and put in EDTA tube (XXXX). The blood was centrifuged with using centrifugation $\left(\right.$ Boeco $^{\circledR}$ ) for $15 \mathrm{~m}$ at $3000 \mathrm{rpm}$ to collect the plasma. Plasma collected were put in microtube and stored in container $\left(-20^{\circ} \mathrm{C}\right)$ for assaying the interferon-gamma (IFN- $\gamma$ ) levels by using ELISA kit IFN- $\gamma\left(\right.$ Invitrogen $\left.^{\circledR}\right)$ and the tumor necrosis factor-alpha (TNF- $\alpha$ ) by using ELISA kit TNF- $\alpha$ (Elabscience $\left.{ }^{\circledR}\right)$.

\section{Statistical Analysis}

Levels of IFN- $\gamma$ and TNF- $\alpha$ were analyzed with SPSS (Statistical Product and Service Solution) using ANOVA and Tukey test.

\section{RESULTS AND DISCUSSION}

In inducing immune responses, Staphylococcus aureus was used in this research. S. aureus contains LTA (lipoteichoic acid), which similar to LPS (lipopolysaccharide) in the gram-negative bacterium. LTA from $S$. aureus can induce an immune response by provoking cytokines secretion, including IFN$\gamma$ and TNF- $\alpha$ (Fournier \& Philpott, 2005). The IFN- $\gamma$ is involved in the activation of cells by stimulating the cytotoxic cells and macrophages, thus lead to cells mediated innate immunity in acute phase responses. Whereas, the TNF- $\alpha$ contributes to acute responses by affecting a variety of cells, including macrophages activation (Wahab \& Hussain, 2013).

The administration of ethanolic extract of Xestospongia sp. in animals induced Staphylococcus aureus is expected to increase the production of IFN- $\gamma$ and TNF- $\alpha$ levels mediated in the acute phase of innate immunity. According to previous research, ethanolic extract of Xestospongia sp. increase the phagocytic activity of macrophages. Macrophages actives in the early stage of innate immunity by 
destroying and eliminating the pathogens, and is mediated by cytokines. (Fristiohady et al., 2019; Hirayama et al., 2018).

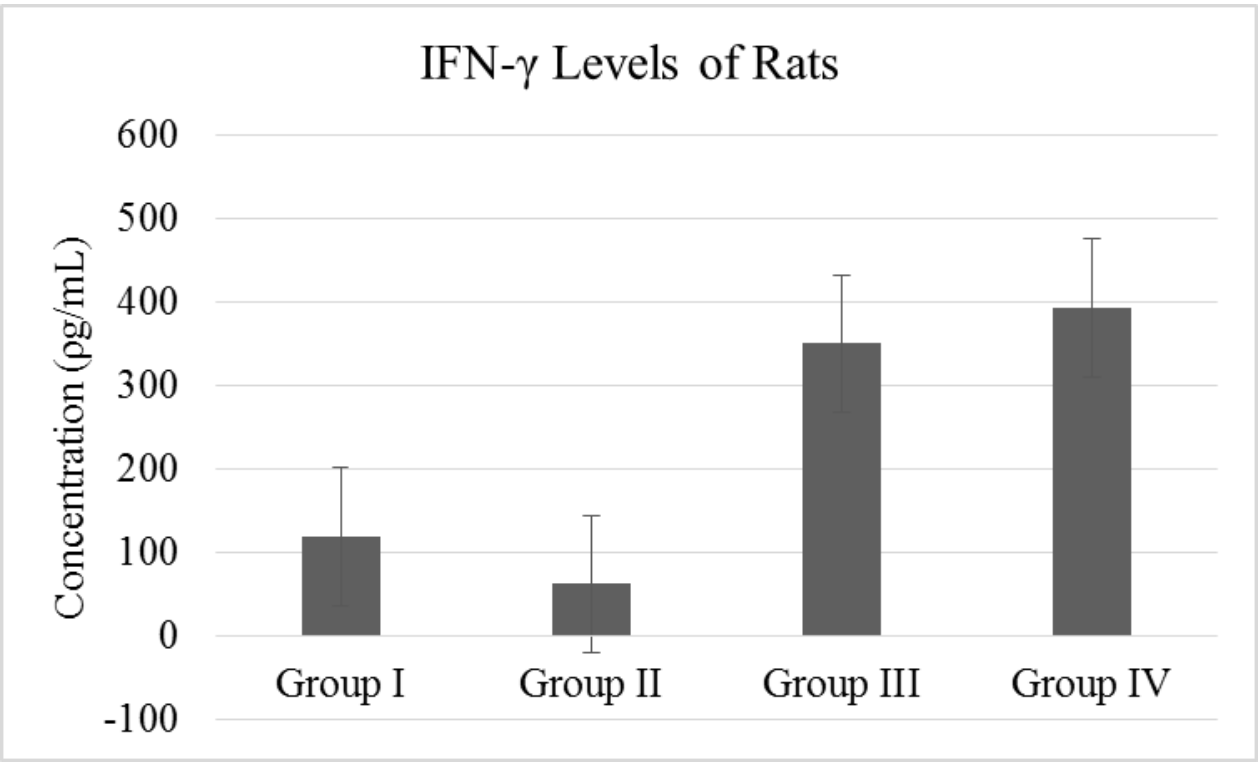

Figure 1. IFN- $\gamma$ Levels of Rats post-treated for 7 days ( $n=4$, Group I $=$ Phylantii extract; Group II $=0.5 \% \mathrm{Na}$ CMC; Group III = XEE dose of $300 \mathrm{mg} / \mathrm{KgBW}$; Group IV = XEE dose of $400 \mathrm{mg} / \mathrm{KgBW}$ )

According to research conducted (Figure 1), both Group III and IV as treatment group were exhibiting increased IFN- $\gamma$ levels to group II as negative group as well to group I as positive group. The IFN- $\gamma$ levels of both group III $(350.113 \mathrm{\rho g} / \mathrm{mL})$ and IV $(392.970 \mathrm{\rho g} / \mathrm{mL})$ were higher than group I (118.417 $\rho \mathrm{g} / \mathrm{mL})$ and Group II $(61.958 \rho \mathrm{g} / \mathrm{mL})(p<0.05)$. Group III provided lower IFN- $\gamma$ levels compared to group IV, although it was not differently significant $(p>0.05)$.

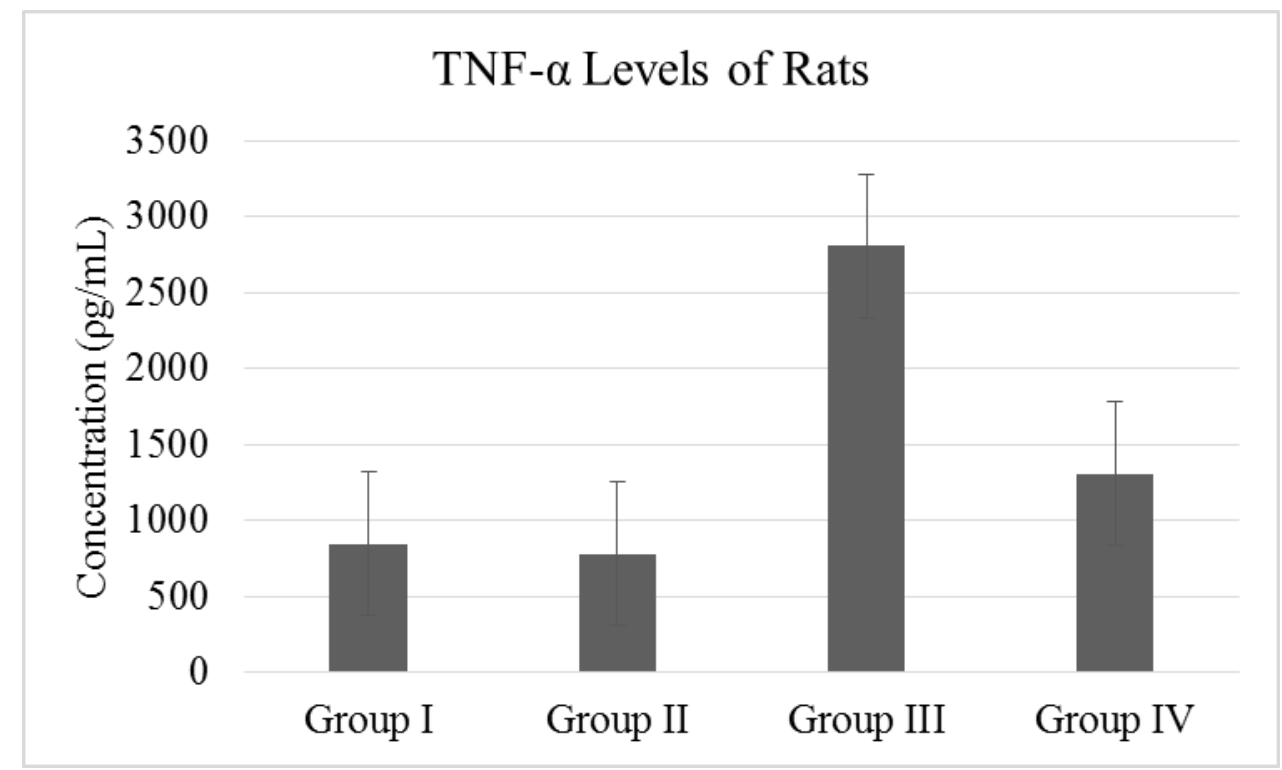

Figure 2. TNF- $\alpha$ Levels of Rats post-treated for 7 days ( $n=4$, Group I $=$ Phylantii extract; Group II $=0.5 \%$ Na CMC; Group III = XEE dose of $300 \mathrm{mg} / \mathrm{KgBW}$; Group IV = XEE dose of $400 \mathrm{mg} / \mathrm{KgBW}$ ) 
The TNF- $\alpha$ levels of rats in treatment groups were exhibiting similar results in IFN- $\gamma$ levels. Both Group III and IV were experiencing increased IFN- $\gamma$ levels compared to Group I as positive group and Group II as negative group. The Group III $(2808 \rho \mathrm{g} / \mathrm{mL})$ and Group IV $(1308 \rho \mathrm{g} / \mathrm{mL})$ TNF- $\alpha$ levels were significantly differenced to Group I $(845.5 \mathrm{\rho g} / \mathrm{mL})$ and Group II $(778 \rho \mathrm{g} / \mathrm{mL})(p<0.05)$. Despite both treatment group exhibited increased TNF- $\alpha$ levels, Group III were providing significant difference levels to Group IV ( $p<0.05)$ (Figure 2).

Xestospongia sp. contains sterols, alkaloids, and saponins (Fristiohady et al., 2019). Sterols contained in Xestospongia sp. are suspected to play a vital role as an immunostimulant. Sterols act similar to tolllike receptor ligands that recognize and bind to immune cells. These bonds activate the NF- $\mathrm{KB}$ as cytokines transcription factors thus increase the secretion of IFN- $\gamma$ levels to extra cells. In addition, it also increases the T-cell stimulation activity as a response in pathogenesis (Egbuna, 2019; Delves, 2017; Sadarun, 2018). IFN- $\gamma$ is the main MAC cytokine (macrophage activation cytokine) that activates macrophages thus phagocytosis progresses rapidly and increases the differentiation of CD4+ cells into Th1 cell subset. IFN- $\gamma$ is produced by activated macrophages, NK (natural killer) cells, and T cells. In addition, IFN- $\gamma$ is an autocrine cytokine that acts on cells that secrete it, and also a paracrine cytokine that affects cells around it (Bratawidjaja\& Iris, 2014).

Despite sterols increase IFN- $\gamma$ levels, the TNF- $\alpha$ levels are presumably increase affected by alkaloids and saponins contained in Xestospongia sp. Alkaloids and saponins stimulate $\mathrm{T}$ lymphocyte cell proliferation and macrophage activation. The $\mathrm{T}$ lymphocytes differentiate into Th1 cells thus produce TNF- $\alpha$. In addition, macrophages produce TNF- $\alpha$ to stimulate immune cells in phagocytosis activity (Solikha and Hesti., 2015; Sudiono, 2014; Kurningtyas et al., 2013).

\section{CONCLUSION}

Ethanolic extract of Xestospongia sp. increases the levels of IFN- $\gamma$ and TNF- $\alpha$ levels at dose of 300 and $400 \mathrm{mg} / \mathrm{KgBW}$. It meand that ethanolic extract of Xestospongia sp. can be used as antiinflammatiry agent and can be developed into dosage form.

\section{ACKNOWLEDGMENT}

Authors thank the Ministry of Research, Technology, and Higher Education of Republic of Indonesia for supporting financially with Hibah Penelitian Dasar Scheme 2019 with Contract number 519a/UN29.20/PPM/2019.

\section{REFERENCES}

Bratawidjaja, K. G., \&Iris, R. (2014). ImunologiDasar. Jakarta: Badan Penerbit Fakultas Ilmu Kedokteran Universitas Indonesia

Chaplin, D. D. (2010). Overview of the Immune Response. J Allergy Clin Immunol, 125(2 Suppl 2): S3-23. Doi: https://doi.org/10.1016/j.jaci.2009.12.980

Delves P. J., Martin, S. J., Burton, D. R.,\&Roitt, I. M. (2017). Roitt's Essential Immunology, 13 ${ }^{\text {th }}$ edition. UK: Wiley-Blackwell

Egbuna, C., Ifemeje J. C., Udedi, S. C., \&Kumar, S. (2019). Phytochemistry Fundamental, Modern Techniques, and Applications Volume I, Canada: Apple Academic Press

El-Gamal, A. A., Al-Massarani, S. M., Shaala, L. A., Alahdald, M. S., Ashour, A. E., Kumar, A. \& et al (2016). Cytotoxic Compounds from the Saudi Red Sea Sponge Xestospongia testudinaria. Mar Drugs, 14(5): 82. Doi: https://doi.org/10.3390Fmd14050082 
Fournier, B., \&Philpott, D.J. (2005). Recognition of Staphylococcus Aureus by the Innate Immune System. Clin Microbiol Rev, 18(3):521-40. Doi:https://doi.org/10.1128/cmr.18.3.521-540.2005

Fristiohady, A., Wahyuni, W., Malik, F., Leorita, M., Yusuf, M. I., \& et al. (2019). Efek Imunomodulator Ekstrak Etanol Spons Xestospongia Sp. Terhadap Aktivitas Fagositosis Makrofag Pada Mencit Jantan Galur Balb/C. Jurnal Mandala Pharmacon Indonesia, 5(01):1530. Doi: https://doi.org/10.35311/jmpi.v5i01.38

Hirayama, D., Iida, T., \& Nakase, H. (2018). The Phagocytic Function of Macrophage-Enforcing Innate Immunity and Tissue Homeostasis. Int $J$ Mol Sci, 19(1): 92. Doi: https://doi.org/10.3390/ijms19010092

Kaihena, Martha.(2013). Propolis Sebagai Imunostimulator Terhadap Infeksi Micobacterium tuberculosis, Prosiding FMIPA Universitas Pattimura.

Kurnianingtyas, E., Djati, M. S., \&Rifa'I, M. (2013). Aktivitas Imunomodulator Polyscias obtusa terhadap Sistem Imunitas pada Bone Marrow Broiler Setelah Pemberian Salmonella typhimurium. Journal Exp.Life Sci,2013;3(1):25-31

Lahlou, M. (2013). The Success of Natural Products in Drug Discovery. Pharmacology \& Pharmacy, 4:17-31. Doi: $\underline{\text { http://dx.doi.org/10.4236/pp.2013.43A003 }}$

Parameswaran, N., \&Patial, S. (2010). Tumor Necrosis Factor- $\alpha$ Signaling in Macrophages. Crit Rev Eukaryot Gene Expr,20(2), 87-103.

Sadarun, B., Malaka, M. H., Wahyuni, W., \&Sahidin, S. (2018). Senyawa Steroid Spons Xestospongia sp. Dari Perairan Sulawesi Tenggara. Pharmuho, 4(1): 26-29. Doi: http://dx.doi.org/10.33772/pharmauho.v4i1.4628

Solikha, A. R.,\&Hesti, M. R. (2015). Pengaruh Ekstrak Lompong (Colocasia esculenta L. Scoot) 30 menit Pengukusan terhadap Aktivitas Fagositosis dan Kadar NO Mencit Balb/C Sebelum dan Sesudah Terinfeksi Listeria monocytogenes. Journal of Nutrition College, 4(2):463-468

Sudiono, J. (2104). Sistem Kekebalan Tubuh, Jakarta: EGC

Turk, T., Avgustin, J. A., Batista, U., Strugar, G., Kosmina, R., Čivović, S., \& et al. (2013). Biological Activities of Ethanolic Extracts from Deep-Sea Antarctic Marine Sponges. Mar Drugs, 11(4): 1126-1139. Doi: https://doi.org/10.3390/md11041126

Wahab, S.,\& Hussain, A. (2013). Cytokines As Targets For Immunomodulation. Int J Pharm Pharm Sci,5 (suppl.3):60-60.

Wahyuni, W., Fristiohady, A., Malaka, M. H., Malik, F., Yusuf, M. I.,Leorita, M., \& et al. (2019). Effects of Indonesian marine sponges ethanol extracts on the lipid profile of hyperlipidemic rats. Journal of Applied Pharmaceutical Science, 9(10):001-008. Doi: https://doi.org/10.7324/JAPS.2019.91001

Wahyuniati, N. (2017). Peran Interferon Gamma pada InfeksiMycobacterium tuberculosis. Jurnal Kedokteran Syiah Kuala, 17(2):126-132. Doi: https://doi.org/10.24815/jks.v17i2.8992 